\title{
Short-term effects of dietary trans fatty acids compared with saturated fatty acids on selected measures of inflammation, fatty acid profiles, and production in early lactating Holstein dairy cows
}

\author{
Jason S. Watts, ${ }^{*}$ Pedram Rezamand, ${ }^{* 1}$ Dallace L. Sevier, $\dagger$ William Price, $\dagger$ and Mark A. McGuire* \\ ${ }^{*}$ Department of Animal and Veterinary Science, and \\ †College of Agricultural and Life Sciences, University of Idaho, Moscow 83844
}

\begin{abstract}
Feeding rations supplemented with fats may provide an opportunity to manipulate the health and performance of dairy cows; however, the relative effects of specific fats, such as trans fatty acids (TFA), are poorly understood. The objective of this study was to investigate the effects of a ration supplemented with TFA on the fatty acid (FA) profile of peripheral blood mononuclear cells (PBMC), plasma lipids, and milk; the gene expression of inflammatory markers; production of acute phase proteins; and production performance in early lactating dairy cows. Trans fat was fed at $0,1.5$, and $3 \%$ of dry matter, replacing (1:1 wt:wt) saturated fatty acids (SFA). Multiparous lactating Holstein cows at $7 \mathrm{~d}$ in milk $(\mathrm{n}=12)$ were randomly assigned to a treatment sequence in a $3 \times 3$ balanced Latin square design; each period lasted $14 \mathrm{~d}$. Milk and heparinized blood were collected on d 0 (pretreatment) and on d 10 and 14 of each period. Plasma was collected and solid-phase extraction was used to isolate plasma phospholipids and nonesterified fatty acids. Additionally, PBMC were isolated for FA analysis and gene expression analysis by reverse transcription-PCR using bovine RPS9 as the endogenous control. The FA composition of PBMC, plasma lipid fractions, and milk were analyzed by gas chromatography. Data were analyzed using the MIXED procedure (SAS Institute Inc., Cary, NC). As dietary TFA increased, the percentage of some 18:1 trans isomers increased in PBMC, plasma lipids, and milk. Dietary TFA had no detectable effect on mRNA expression of proinflammatory $T N F \alpha$ or IL6. Expression of $I L 1 \beta$ and ICAM1 decreased with increasing TFA. In addition, supplementation of TFA did not affect percentages of milk fat, protein, lactose, or solids-not-fat, or somatic cell count. Overall, dietary TFA increased the trans FA present in PBMC, plasma lipids, and milk; however, dietary TFA decreased
\end{abstract}

Received November 27, 2012.

Accepted July 17, 2013.

${ }^{1}$ Corresponding author: rezamand@uidaho.edu
PBMC expression of some of the proinflammatory markers tested at the mRNA level compared with SFA in early lactating dairy cows. Together, these findings provide evidence that over short period of times, dietary TFA might be slightly less immune-stimulatory than dietary SFA.

Key words: trans fat, inflammation, fatty acid, gene expression

\section{INTRODUCTION}

Acute inflammation contributes to the occurrence and severity of economically important diseases such as mastitis (Contreras and Rodríguez, 2011). In addition to providing energy and serving as critical structural components of all cells, dietary fats play a critical role in both the precipitation and resolution of inflammation (Calder, 2008). Furthermore, the various structural properties of FA correspond to different functional properties within a cell. Saturated fats and trans fats are 2 distinct groups of FA that have garnered a great deal of attention for their potential negative effects on health. The presence of trans fats in the human diet, in particular, has come under intense public scrutiny in recent years. Consumption of trans fats is associated with induction of systemic inflammation and represents a greater dietary risk factor for cardiovascular disease than saturated fat (Mozaffarian, 2006). The trans double bond results in FA more structurally similar to saturated fats than to naturally occurring cis unsaturated fatty acids (UFA), leading to reduced cell membrane fluidity and possibly altered cell signaling (Roach et al., 2004). Naturally occurring trans FA arise during biohydrogenation of UFA in the rumen; however, the main source of trans fats in the human diet is from industrial hydrogenation of vegetable oils (Steinhart et al., 2003). Dietary trans FA (TFA) are associated with induction of an inflammatory state via production of proinflammatory cytokines by cells of the immune system and the endothelium (Han et al., 2002; Harvey et al., 2008). During the periparturient period, when cows are particularly susceptible to infection and 
inflammation, shifts in the composition of plasma lipids are coupled with changes in the FA composition of immune cells (Contreras et al., 2010), and if fed, TFA have the potential to integrate into cell membranes and alter immune cell function through various processes, including alteration in expression of genes encoding for proinflammatory mediators (Calder, 2008). We have recently demonstrated that in an in vitro model of bovine mammary epithelial cells, TFA, compared with no trans FA, increased mRNA expression of both $I L-1 \beta$ and intracellular adhesion molecule $(\boldsymbol{I C A} \boldsymbol{M})-1$ (Rezamand and McGuire, 2011), although mammary epithelial cells (in vitro) and mononuclear cells (ex vivo) may behave differently in response to TFA treatment. Changes in gene expression at the epithelium or in circulating immune cells have the potential to systemically alter the inflammatory state of an animal. In response to an immune stressor, cytokines produced locally by monocytes, macrophages, or epithelial cells act systemically by signaling the liver to produce acute phase proteins (Petersen et al., 2004). Concentration of the acute phase protein haptoglobin usually peaks in healthy cows shortly after parturition at $>0.5 \mathrm{mg} /$ $\mathrm{mL}$ and then typically returns to $<0.3 \mathrm{mg} / \mathrm{mL}$ by the second week postpartum (Humblet et al., 2006; Huzzey et al., 2009). Haptoglobin concentration was previously shown to be modified by dietary safflower oil during the periparturient period due to alterations in the ratio of n-6 to n-3 PUFA (Silvestre et al., 2011).

Therefore, we hypothesized that increasing dietary intake of trans fat, compared with increasing dietary SFA, would increase TFA incorporation into plasma lipid fractions and peripheral blood mononuclear cells (PBMC; as circulating immune cells, which includes both monocytes and lymphocytes, responsive to dietary treatment), and thus upregulate gene expression of inflammatory mediators in PBMC and increase the plasma concentration of acute phase proteins.

The objective of the present research was to investigate the ability of calcium salts of TFA fed to periparturient Holstein cows to be incorporated into plasma lipid fractions and PBMC compared with a diet providing SFA. A specific aim of the study was to determine if dietary TFA would alter the FA composition of PBMC and affect basal expression of proinflammatory cytokines and adhesion molecules in PBMC compared with dietary SFA.

\section{MATERIALS AND METHODS}

\section{Animals, Treatments, and Experimental Design}

Twelve multiparous Holstein cows at 7 DIM were randomly assigned to a treatment sequence in repli- cated paired $3 \times 3$ balanced Latin squares. Cows were fed 3 diets containing a graded amount of calcium salt of TFA (EnerGTR; Virtus Nutrition, Corcoran, CA) and SFA (EnerGII; Virtus Nutrition). The FA composition of the supplements is shown in Table 1. Mixtures of TFA and SFA were completely mixed into a lactation ration at $3 \%$ of diet DM to contain 3\% SFA (SAT), 1.5\% SFA:1.5\% TFA (MIX), or 3\% TFA (TRANS). The basal lactation ration $(50.2 \% \mathrm{DM})$ consisted of (on a DM basis) dairy alfalfa (11.65\%), triticale silage $(45.32 \%)$, canola meal $(9.71 \%)$, dried distillers grain $(9.71 \%)$, rolled corn $(9.71 \%)$, rolled barley $(11.65 \%)$, sodium bicarbonate $(0.33 \%)$, and a premix of minerals and vitamins $(1.94 \%)$ that contained $\mathrm{Ca}(17.5 \%)$, $\mathrm{P}(0.17 \%), \mathrm{S}(0.3 \%), \mathrm{Mg}(3.1 \%), \mathrm{Fe}(812 \mathrm{mg} / \mathrm{kg}), \mathrm{Zn}$ $(2,822 \mathrm{mg} / \mathrm{kg}), \mathrm{Mn}(1,741 \mathrm{mg} / \mathrm{kg})$, Se $(13.5 \mathrm{mg} / \mathrm{kg})$, vitamin A $(275,000 \mathrm{IU} / \mathrm{kg})$, vitamin $\mathrm{D}(77,000 \mathrm{IU} /$ $\mathrm{kg})$, and vitamin $\mathrm{E}(1320 \mathrm{IU} / \mathrm{kg})$. The basal ration to which supplemental fats were added contained (on a DM basis) $18 \pm 1.00 \% \mathrm{CP}(34.7 \%$ soluble protein as a $\%$ of $\mathrm{CP}), 25.8 \pm 1.77 \% \mathrm{ADF}, 39.3 \pm 2.65 \% \mathrm{NDF}$, $5.43 \pm 0.13 \%$ lignin, $3.63 \pm 0.12 \%$ ether extract, 8.39 $\pm 0.09 \%$ ash, $0.72 \pm 0.08 \% \mathrm{Ca}, 0.46 \pm 0.02 \% \mathrm{P}, 1.55$ $\pm 0.06 \% \mathrm{~K}, 0.30 \pm 0.01 \% \mathrm{Mg}$, and $1.52 \pm 0.02 \mathrm{Mcal}$ of $\mathrm{NE}_{\mathrm{L}} / \mathrm{kg}$. Cows were housed in individual box stalls and milked twice daily at 0700 and $1900 \mathrm{~h}$. Diets were fed ad libitum twice daily to ensure 5 to $10 \%$ orts. Feed was provided for each cow individually, and intake and milk yield were recorded daily. After each 14-d period, cows were moved to the next treatment without any washout period. All animal procedures were approved by the University of Idaho Animal Care and Use Committee (protocol 2010-29).

\section{Sample Collection}

Pretreatment samples (d 0) were taken when each cow reached 7 DIM, and blood and milk samples were taken on d 10 and 14 of each period. Blood was collected via coccygeal venipuncture using 10-mL BD Vacutainer tubes containing 143 USP units of sodium heparin (BD Diagnostics, Franklin Lakes, NJ). Peripheral blood mononucleocytes were isolated from $15 \mathrm{~mL}$ of blood by gradient centrifugation using Histopaque 1077 (Sigma Aldrich, St. Louis, MO). Blood was mixed 1:1 with PBS-citrate dextrose solution (80:20 vol:vol). The mix was layered on Histopaque 1077. After centrifugation at $456 \times g$ for $1 \mathrm{~h}$ at room temperature, plasma was collected and stored at $-80^{\circ} \mathrm{C}$. The buffy coat was collected and washed $3 \times$ with $50 \mathrm{~mL}$ of PBS:acid citrate dextrose. To lyse remaining red blood cells, $2 \mathrm{~mL}$ of water was briefly added to the cell pellet, and then the cells were resuspended in PBS, aliquoted, and stored at $-80^{\circ} \mathrm{C}$ for RNA and FA analysis. Cells collected for 
Table 1. Fatty acid composition of trans fat (TFA) and saturated fat (SAT) used as experimental fat supplements

\begin{tabular}{|c|c|c|}
\hline $\mathrm{FA},{ }^{1} \mathrm{~g} / 100 \mathrm{~g}$ & $\mathrm{TFA}^{2}$ & $\mathrm{SAT}^{3}$ \\
\hline C6:0 & 0.3 & - \\
\hline C8:0 & 0.4 & - \\
\hline C10:0 & 0.1 & - \\
\hline C12:0 & - & 0.3 \\
\hline C14:0 & 0.2 & 1.2 \\
\hline C16:0 & 14.1 & 48.4 \\
\hline C16:1 & - & 0.2 \\
\hline $\mathrm{C} 16: 1$ trans & 0.1 & - \\
\hline C17:0 & - & 0.1 \\
\hline C18:0 & 9.3 & 4.2 \\
\hline C18:1 trans-5 & 0.1 & - \\
\hline $\mathrm{C} 18: 1$ trans- $6-8$ & 4.3 & - \\
\hline C18:1 trans-9 & 12.9 & - \\
\hline C18:1 trans -10 & 10.6 & - \\
\hline C18:1 trans-11 & 8.5 & - \\
\hline C18:1 trans -12 & 5.9 & - \\
\hline C18:1 trans-13-14 & 4.2 & - \\
\hline C18:1 cis-9 & 6.9 & 35.4 \\
\hline C18:1 cis-10 & 2.2 & - \\
\hline C18:1 cis-11 & 2.0 & - \\
\hline C18:1 cis-12 & 1.5 & 0.9 \\
\hline C18:1 cis-13 & 0.6 & - \\
\hline C18:1 trans -16 & 0.1 & - \\
\hline C18:1 cis-14 & 1.2 & - \\
\hline C18:1 cis-15 & 1.3 & - \\
\hline C18:2 trans-9,trans-12 & 6.2 & - \\
\hline C18:2 CLA $^{4}$ & 4.1 & - \\
\hline $18: 2 n-6$ & 0.4 & 8.5 \\
\hline C20:0 & 0.4 & 0.2 \\
\hline $\mathrm{C} 22: 0$ & 0.4 & - \\
\hline $\mathrm{C} 24: 0$ & 0.1 & - \\
\hline Others & 1.7 & 0.5 \\
\hline Total trans & 46.6 & 0.15 \\
\hline
\end{tabular}

${ }^{1}$ Fatty acid composition was provided by Virtus Nutrition (Corcoran, CA).

${ }^{2}$ EnerGTR; calcium salts of trans fatty acids (Virtus Nutrition).

${ }^{3}$ EnerGII; calcium salts of saturated fatty acids (Virtus Nutrition).

${ }^{4}$ Conjugated linoleic acid.

gene expression assays were mixed with Trizol, homogenized with Qiashredder columns (Qiagen, Valencia, $\mathrm{CA}$ ), and stored at $-80^{\circ} \mathrm{C}$ before RNA extraction.

Milk was collected at both milkings on the sampling days (d 10 and 14) and pooled proportionally to the yield at each milking. Fifteen milliliters was stored at $-20^{\circ} \mathrm{C}$ for FA analysis. Milk was analyzed for fat, true protein, lactose, SNF, and SCC by near infrared analysis (Washington DHIA, Burlington, WA).

Feed samples were collected weekly for DM determination from the basal ration. Weekly samples were then composited and chemical composition was determined via near infrared and wet chemistry analyses by Forage One Laboratory (Ithaca, NY).

\section{Lipid Analysis}

Milk, plasma, and PBMC lipids were extracted using chloroform:methanol $(2: 1)$ as described previ- ously (Clark et al., 1982). Plasma lipids were further separated into neutral lipids, NEFA, and phospholipids (PL) by solid-phase extraction using Sep-Pak aminopropyl cartridges (Waters, Milford, MA) as described previously (Kaluzny et al., 1985). Milk lipids, PBMC lipids, and PL were converted to FA methyl esters using sodium methoxide methylation as described (Christie, 1982). The NEFA were methylated with $5 \%$ methanolic hydrochloric acid for $10 \mathrm{~min}$ at $80^{\circ} \mathrm{C}$. Fatty acid methyl esters were analyzed using an Agilent 7890A gas-chromatography system (Agilent Technologies, Santa Clara, $\mathrm{CA}$ ) fitted with an autosampler, a flame-ionization detector, and an Agilent HP-88 column $(100 \mathrm{~m} \times 0.25$ $\mathrm{mm}$ with $0.2-\mu \mathrm{m}$ film thickness, Agilent Technologies). After sample injection, the oven temperature was $120^{\circ} \mathrm{C}$ for $1 \mathrm{~min}$, increased to $175^{\circ} \mathrm{C}$ at a rate of $10^{\circ} \mathrm{C} / \mathrm{min}$ and held for $10 \mathrm{~min}$, increased to $210^{\circ} \mathrm{C}$ and held for $5 \mathrm{~min}$, increased to $230^{\circ} \mathrm{C}$ at a rate of $5^{\circ} \mathrm{C} / \mathrm{min}$ and held for $5 \mathrm{~min}$, and increased $5^{\circ} \mathrm{C} / \mathrm{min}$ to $240^{\circ} \mathrm{C}$ and held for 5 min. Individual FA were identified by comparison with a butter oil standard with certified values (CRM 164; European Community Bureau of Reference, Brussels, Belgium), a Supelco 37 FAME standard mixture (Supelco, Bellefonte, PA), and individual FAME standards for 18:1 trans-9, 18:1 trans-11, 18:1 trans-12, and 18:2 trans-9,trans-12 (Supelco).

Plasma total NEFA concentrations were determined using the NEFA-HR-2 Kit (Wako, Richmond, VA) according to the manufacturer's instructions and read on a Wallac Victor 2 Microplate spectrophotometer (PerkinElmer, Norwalk, CT). The inter- and intraassay CV were 8.3 and $6.1 \%$, respectively.

\section{Gene Expression Analysis}

Total RNA was extracted from PBMC using the RNeasy Mini Plus Kit (Qiagen), and a NanoDrop ND-1000 spectrophotometer (NanoDrop Technologies, Rockland, DE) was used to determine RNA concentration and purity. To assess RNA integrity, a randomly chosen subset of samples was analyzed with an Agilent 2100 Bioanalyzer (Agilent Technologies). The average RNA integrity number for these samples was $7.76 \pm$ $0.28(\mathrm{n}=11)$. Gene expression of samples taken on $\mathrm{d}$ 10 and 14 of each treatment $(\mathrm{n}=72)$ and pretreatment samples $(\mathrm{n}=12)$ were analyzed by reverse transcription (RT)-PCR as previously described (Shields et al., 2011). Expression of $I L 1 \beta$, IL6, tumor necrosis factor $\alpha(\boldsymbol{T N F} \boldsymbol{\alpha}), I C A M-1, I L 2$, and IL-2 receptor subunit $\alpha(I L 2 R \alpha)$ were measured relative to a housekeeping gene, ribosomal protein S9 ( $\boldsymbol{R P S 9})$. Primer Express (version 1.5, Applied Biosystems, Foster City, CA) was used to generate primer/probe sets for PCR amplification, and NCBI Primer-BLAST (National Center for 
Table 2. Custom bovine primer/probe sets used for reverse transcription-PCR ${ }^{1}$

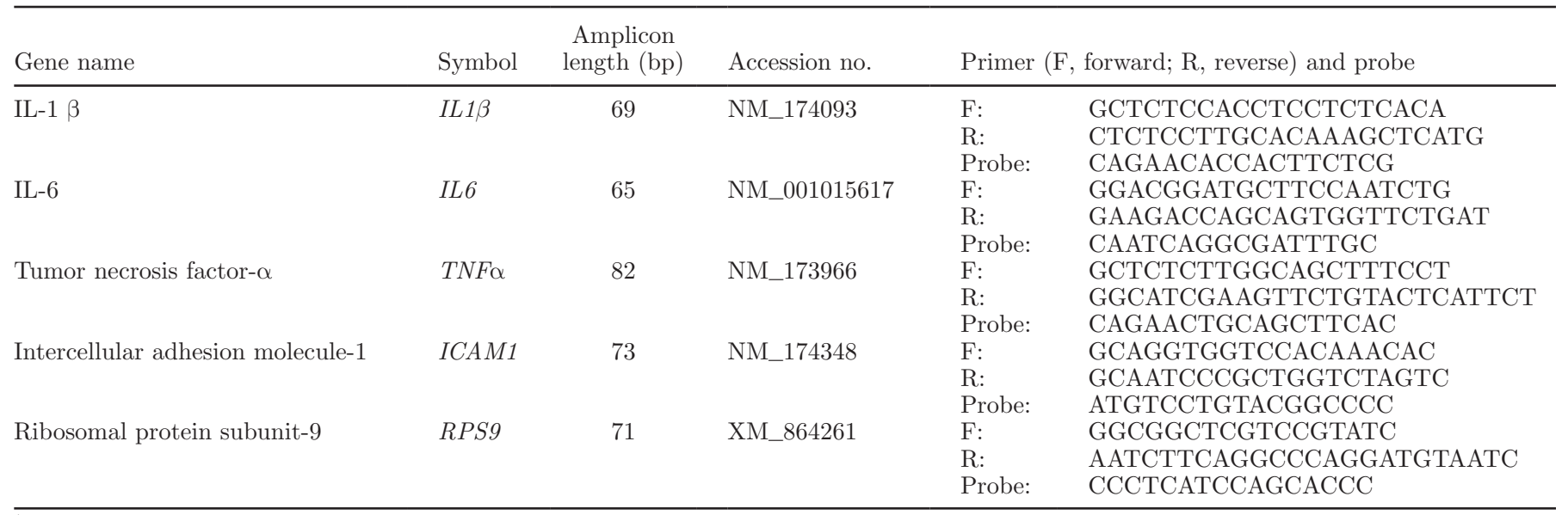

${ }^{1}$ Primers were designed using Primer Express software v. 1.5 (Applied Biosystems, Foster City, CA).

Biotechnology Information; http://www.ncbi.nlm.nih. gov/tools/primer-blast/) was used to check for potential off-target amplification (Table 2). Bovine IL2 and IL2R $\alpha$ primer/probe sets were developed by Applied Biosystems (assay numbers Bt03217368_m1 and Bt03213930_m1, respectively).

\section{Plasma Haptoglobin}

Plasma haptoglobin concentrations were determined colorimetrically based on binding of free hemoglobin using the phase haptoglobin assay (TriDelta Diagnostics Inc., Morris Plains, NJ). The inter-and intraassay CV were 5.7 and $10.5 \%$, respectively.

\section{Statistical Analysis}

Statistical analysis was performed using the MIXED procedure of SAS (version 9.2, SAS Institute Inc., Cary, NC). All data were analyzed in a $3 \times 3$ Latin square design with 3 treatments and 3 periods. Sources of variation in the model included effects of dietary treatment, day, and treatment $x$ day interaction. Cow nested within square was designated as a random effect in the model. Samples taken on d 10 and 14 of each period were used for analysis of treatment and time. A baseline sample taken pretreatment at d 0 for each cow was used as a covariate, when appropriate. When a significant treatment effect $(P<0.05)$ was observed, mean comparisons were then performed using the pdiff command of SAS. Gene expression data were analyzed using cycle threshold $(\mathrm{Ct})$ values normalized by subtraction to the housekeeping gene, RPS9. Gene expression data are presented as fold change $\left(2^{-\Delta \Delta \mathrm{Ct}}\right)$ relative to the SAT diet.

\section{RESULTS AND DISCUSSION}

\section{Performance Measures}

No differences were detected in DMI (15.8, 16.7 and $15.7 \pm 0.94 \mathrm{~kg} / \mathrm{d}$ ) or milk production $(33.5,34.3$ and $33.2 \pm 1.91 \mathrm{~kg} / \mathrm{d}$ ) for cows fed SAT, MIX, and TRANS, respectively. As expected, inclusion of dietary TFA increased $(P<0.0001)$ daily intake of TFA. No differences among treatments were detected for milk yield $(1.00,0.86$, and $0.85 \pm 0.14 \mathrm{~kg} / \mathrm{d})$, protein percentage and yield $(2.84,2.84$, and $2.92 \pm 0.06 \%$ and $0.94,0.94$, and $0.97 \pm 0.05 \mathrm{~kg} / \mathrm{d}$ ), lactose percentage and yield $(4.92,4.92$, and $4.91 \pm 0.04 \%$ and $1.65,1.64$, and 1.63 $\pm 0.09 \mathrm{~kg} / \mathrm{d})$, SNF percentage $(8.62,8.64$, and 8.71 $\pm 0.08 \%$ ), or SCC $(97.6,101.8$, and $140.7 \pm 29.4 \times$ $10^{3}$ cells $/ \mathrm{mL}$ ) for cows fed SAT, MIX, and TRANS, respectively.

\section{FA Composition}

$\boldsymbol{P B} \boldsymbol{M C}$. In the present study, increasing TFA in the rations resulted in moderate alterations in the FA profile of PBMC. Notably, specific 18:1 trans isomers increased (Table 3). The most abundant FA present in PBMC total lipids were palmitic acid (C16:0), stearic acid (C18:0), oleic acid (C18:1 cis-9), linoleic acid (C18:2 cis-9,cis-12), and arachidonic acid (C20:4n-6). Total C18:1 trans isomers did not increase with TFA treatment; however, both the C18:1 trans-10 and trans-12 isomers increased $(P<0.01)$ with increasing TFA treatment. The C18:1 trans- 10 were $0.21,0.23$, and $0.33 \%$ for SAT, MIX, and TRANS treatments, respectively, with a difference $(P=0.02)$ detected between TRANS and the SAT and MIX treatments. Similarly, C18:1 trans-12 concentration was greater $(P$ 
$=0.01)$ with TRANS treatment compared with SFA or MIX, although no difference was detected between SAT and MIX. The C18:1 trans-12 was 0.19, 0.24, and $0.33 \%$ of FA for SAT, MIX, and TRANS treatments, respectively. Trans isomers of C18:2 were not detected in PBMC. Treatments did not affect total MUFA, total PUFA, total UFA, n-6 to n-3 ratio, or total SFA in PBMC total lipids.

Kew et al. (2003) demonstrated that variations in FA composition of PBMC phospholipids affect immune cell responsiveness to inflammatory stimuli. In cows, PBMC lipids are altered by changes in the diet and possibly by lipid mobilization during the periparturient period (Contreras et al., 2010). The current study demonstrates that dietary TFA are integrated into the FA of PBMC although only at the maximum dietary incorporation. Integration of TFA into PBMC lipids is thought to play an important role in the proinflammatory effects of TFA consumption, contributing to chronic disease (Mozaffarian, 2006). Replacing cis-UFA with trans FA reduces membrane fluidity and could alter cellular signaling (Roach et al., 2004). Mozaffarian (2006) presented a possible mechanism for TFAinduced inflammation, in which membrane TFA induce the release of proinflammatory cytokines either through altered toll-like receptor activity at the cell surface or by binding of TFA to nuclear receptors and altering gene expression via nuclear factor- $\kappa \mathrm{B}(\mathrm{NF}-\kappa \mathrm{B})$.

Plasma PL. Although the extent to which different plasma lipid fractions contribute FA to PBMC is unknown, the FA composition of plasma PL correlates well with the cell membrane FA composition of leukocytes

Table 3. Fatty acid composition of peripheral blood mononucleocytes (PBMC) isolated from early lactation Holstein cows $(n=12)$ fed various fat supplements ${ }^{1}$

\begin{tabular}{|c|c|c|c|c|c|}
\hline \multirow{2}{*}{$\begin{array}{l}\mathrm{FA}, \\
\% \text { of total }\end{array}$} & \multicolumn{3}{|c|}{ Ration $^{2}$} & \multirow[b]{2}{*}{ SEM } & \multirow[b]{2}{*}{$P$-value } \\
\hline & SAT & MIX & TRANS & & \\
\hline \multicolumn{6}{|l|}{ SFA } \\
\hline C14:0 & 0.35 & 0.36 & 0.33 & 0.06 & 0.89 \\
\hline C15:0 & 0.35 & 0.37 & 0.40 & 0.03 & 0.34 \\
\hline C16:0 & 16.86 & 16.98 & 16.30 & 0.70 & 0.67 \\
\hline C17:0 & 0.81 & 0.75 & 0.79 & 0.04 & 0.54 \\
\hline C18:0 & 36.25 & 38.73 & 39.35 & 3.07 & 0.73 \\
\hline $\mathrm{C} 20: 0$ & 0.21 & 0.22 & 0.22 & 0.02 & 0.87 \\
\hline$\Sigma$ SFA & 54.82 & 57.42 & 57.39 & 2.15 & 0.56 \\
\hline \multicolumn{6}{|c|}{ Unsaturated FA (UFA) } \\
\hline C18:1 cis-9 & 12.80 & 12.77 & 12.34 & 0.89 & 0.92 \\
\hline C18:1 cis-11 & 1.48 & 1.47 & 1.42 & 0.19 & 0.97 \\
\hline C18:1 cis-12 & 0.91 & 0.96 & 1.05 & 0.10 & 0.63 \\
\hline C18:1 cis-13 & 0.28 & 0.31 & 0.39 & 0.06 & 0.45 \\
\hline C18:1 cis-14 & 0.15 & 0.16 & 0.16 & 0.02 & 0.70 \\
\hline C18:1 cis-15 & 0.85 & 0.81 & 0.55 & 0.15 & 0.27 \\
\hline \multicolumn{6}{|l|}{ Trans 18:1 } \\
\hline C18:1 trans- $6-8$ & 0.09 & 0.09 & 0.11 & 0.01 & 0.58 \\
\hline C18:1 trans-9 & 0.11 & 0.10 & 0.16 & 0.03 & 0.33 \\
\hline C18:1 trans-10 & $0.21^{\mathrm{a}}$ & $0.23^{\mathrm{a}}$ & $0.33^{\mathrm{b}}$ & 0.03 & 0.02 \\
\hline C18:1 trans-11 & 0.61 & 0.62 & 0.68 & 0.06 & 0.64 \\
\hline C18:1 trans -12 & $0.19^{\mathrm{a}}$ & $0.24^{\mathrm{a}}$ & $0.33^{\mathrm{b}}$ & 0.03 & 0.01 \\
\hline$\Sigma$ Trans $18: 1$ & 1.22 & 1.27 & 1.60 & 0.13 & 0.10 \\
\hline$\Sigma$ MUFA & 19.97 & 19.99 & 19.77 & 1.20 & 0.99 \\
\hline C18:2 cis-9,cis-12 & 8.51 & 8.42 & 8.10 & 0.54 & 0.83 \\
\hline C18:3n-6 & 0.20 & 0.13 & 0.11 & 0.04 & 0.25 \\
\hline C18:3n-3 & 0.38 & 0.38 & 0.32 & 0.07 & 0.72 \\
\hline $\mathrm{C} 20: 2$ & 1.48 & 0.79 & 0.70 & 0.48 & 0.44 \\
\hline C20:3n-6 & 3.22 & 2.74 & 3.10 & 0.24 & 0.34 \\
\hline C20:4n-6 & 10.82 & 9.47 & 9.97 & 0.71 & 0.41 \\
\hline C20:5n-3 & 0.60 & 0.66 & 0.54 & 0.08 & 0.31 \\
\hline C24:1n-9 & 2.28 & 2.22 & 2.26 & 0.21 & 0.98 \\
\hline$\Sigma$ PUFA & 25.21 & 22.59 & 22.84 & 1.44 & 0.33 \\
\hline$\Sigma$ UFA & 45.18 & 42.58 & 42.61 & 2.46 & 0.69 \\
\hline UFA:SFA ratio & 0.90 & 0.82 & 0.80 & 0.07 & 0.62 \\
\hline
\end{tabular}

${ }^{\mathrm{a}, \mathrm{b}}$ Treatment means in a row that do not share a common letter are different $(P<0.05)$.

${ }^{1}$ Periods lasted $14 \mathrm{~d}$ with treatments beginning on d 7 postpartum. Samples were taken on d 10 and 14 of each period.

${ }^{2}$ SAT $=$ EnerGII calcium salts of fatty acids provided by Virtus Nutrition (Corcoran, CA) comprising $3 \%$ of DM; MIX $=1: 1$ mix of SAT and TRANS at $3 \%$ of DM; TRANS = EnerGTR calcium salts of fatty acids provided by Virtus Nutrition comprising $3 \%$ of DM. 
in cows (Contreras et al., 2010). Treatments did not affect MUFA, PUFA, total UFA, total SFA, or the ratio of UFA:SFA of plasma PL (Table 4). The predominant FA in plasma PL across all treatments were linoleic acid (C18:2 cis-9,cis-12, 29.7\%), stearic acid (C18:0, 24\%), palmitic acid (C16:0, 18.7\%) and oleic acid (C18:1 cis$9,12.9 \%$ ) in the present study (Table 4), similar to the composition reported for late-lactation Holstein cows (Tyburczy et al., 2008). Conflicting results have been reported, however, for plasma PL. Contreras et al. (2010) reported stearic and palmitic acid to be the most abundant FA in plasma PL at parturition and through early lactation, with considerably less linoleic acid $(<11 \%)$. This discrepancy is likely because of a greater extent of plasma PL originating from dietary FA as opposed to mobilization of fat stores in the current study. In the present study, rations contained a high concentration of FA (6.63\%) and FA in the basal lactation ration were provided by canola meal, known to be high in oleic acid as well as linoleic acid (Hristov et al., 2011). Conversely, the ration used by Contreras et al. (2010) contained 3.9\% ether extract.

Increasing consumption of TFA increased the total amount of trans C18:1 isomers in plasma PL, but did not alter the concentration of any C18:2 isomers (Table 4). Concentration of $\mathrm{C} 18: 1$ trans $-4-5$, trans -9 , and trans-12 in TRANS cows increased by 75,125 , and $42 \%$ compared with SAT, respectively (Table 4). Concentration of trans 18:1 isomers was not different, however, between the MIX and TRANS groups. No difference was detected among treatments for the most prominent C18:1 trans isomer, trans-11 (0.39\% of FA in PL), even though it was nearly $9 \%$ of the TFA supplement. The changes in plasma PL C18:1 trans isomers in the present study are modest compared with the changes in concentration attained through abomasal infusion of trans isomers (Tyburczy et al., 2008), in which more than a 6-fold increase in elaidic acid (18:1 trans-9) was reported for cows abomasally infused with $41.7 \mathrm{~g} / \mathrm{d}$ of elaidic acid. In the present study, cows fed TRANS consumed approximately $21 \mathrm{~g} / \mathrm{d}$ of elaidic acid, but only a $125 \%$ increase was observed. This suggests that, in the current study, absorption of TFA may have been decreased or that elaidic acid was altered in the rumen. Several studies have shown that substantial biohydrogenation of FA takes place even when fed in the form of calcium salts (Theurer et al., 2009; Caldari-Torres et al., 2011). Therefore, it is likely that trans 18:1 isomers underwent some ruminal biohydrogenation, reducing the total amount of 18:1 isomers available for incorporation into plasma lipids.

Plasma NEFA. Total plasma NEFA concentration was high at $7 \mathrm{~d}$ postpartum and decreased during each experimental period, but was not affected by treatments. During the experimental periods, plasma NEFA concentration was $0.48 \mathrm{mEq} / \mathrm{L} \pm 0.03$ across all treatments, and was $0.47,0.48$, and $0.47 \mathrm{mEq} / \mathrm{L} \pm$ 0.05 for SAT, MIX, and TRANS, respectively. Highproducing dairy cows typically experience a period of negative energy balance around parturition so energy reserves are mobilized to meet the energy demands. As a result, plasma NEFA increase during the first 10 to 15 d postpartum and return to prepartum concentrations 3 to 4 wk postpartum.

The most prominent FA present in plasma NEFA (Table 5) were stearic acid (C18:0, 31.9\%), palmitic acid (C16:0, 24.6\%), and oleic acid (C18:1 cis-9, $25.2 \%$ ), similar to the FA composition of plasma NEFA reported during late lactation (Tyburczy et al., 2008) and around parturition (Contreras et al., 2010). No differences in total SFA, UFA, MUFA, or PUFA of NEFA were detected among treatments. Treatment effects were observed, however, for the individual SFA isomers $\mathrm{C} 15: 0$ and $\mathrm{C} 16: 0(P=0.04$ for both; Table $5)$. The concentration of C16:0 was greater when cows were fed SAT or MIX compared with TRANS, likely related, at least in part, to the high concentration of C16:0 in the SAT and MIX rations; however, all trans isomers of C18:1 increased with increasing TFA, as did the sum total of trans $\mathrm{C} 18: 1$ isomers. Additionally, cis isomers of $\mathrm{C} 18: 1$, which were also components of the TRANS ration, including $\mathrm{C} 18: 1$ cis-12, cis-13, and cis14, increased with increasing TFA (Table 5). Although cis isomers of C18:1 are known to be normally present in ruminants (Parodi, 1976; Precht et al., 2001), likely resulting from biohydrogenation of trans 18:1 isomers (Proell et al., 2002), limited information on these isomers is available in the literature and any potential role in inflammation has not been studied.

These results further indicate that plasma NEFA composition is susceptible to short-term dietary modification. This has important implications for the health of cows early in lactation.

Milk FA Composition. In the present study, MUFA, including trans and cis isomers of C18:1 (Table 6 ), were increased with increasing dietary TFA. Conversely, palmitic acid (C16:0) increased with increasing SFA. Several studies have demonstrated that infusions of C18:1 trans isomers are efficiently incorporated into milk FA, and that some are altered by $\Delta^{9}$-desaturase activity in the mammary gland (Griinari et al., 2000; Shingfield et al., 2007; Tyburczy et al., 2008). Even though C18:1 trans-11 (trans vaccenic acid) increased with dietary TFA in the current study, a treatment effect was not detected for its $\Delta^{9}$-desaturase product, C18:2 cis-9,trans-11. However, C18:2 trans-10, cis-12 was increased $(P<0.001)$ from $0.01 \%$ of milk fat in SFA-fed cows to $0.02 \%$ in TFA-fed cows. Baumgard 
Table 4. Plasma phospholipid FA composition of early lactation Holstein cows $(\mathrm{n}=12)$ fed various fat supplements ${ }^{1}$

\begin{tabular}{|c|c|c|c|c|c|}
\hline \multirow{2}{*}{$\begin{array}{l}\mathrm{FA}, \\
\% \text { of total }\end{array}$} & \multicolumn{3}{|c|}{ Ration $^{2}$} & \multirow[b]{2}{*}{ SEM } & \multirow[b]{2}{*}{$P$-value } \\
\hline & SAT & MIX & TRANS & & \\
\hline \multicolumn{6}{|l|}{ SFA } \\
\hline C6:0 & 0.08 & 0.12 & 0.05 & 0.03 & 0.26 \\
\hline C8:0 & 0.09 & 0.06 & 0.04 & 0.06 & 0.52 \\
\hline C10:0 & 0.02 & 0.03 & 0.01 & 0.02 & 0.56 \\
\hline C11:0 & 0.01 & 0.01 & 0.01 & 0.00 & 0.95 \\
\hline $\mathrm{C} 12: 0$ & 0.02 & 0.02 & 0.02 & 0.00 & 0.61 \\
\hline C13:0 & 0.05 & 0.04 & 0.04 & 0.01 & 0.41 \\
\hline C14:0 & 0.09 & 0.10 & 0.09 & 0.01 & 0.69 \\
\hline C15:0 & 0.28 & 0.30 & 0.30 & 0.03 & 0.75 \\
\hline C16:0 & 18.87 & 18.95 & 18.41 & 0.63 & 0.78 \\
\hline C17:0 & 0.54 & 0.49 & 0.62 & 0.07 & 0.44 \\
\hline C18:0 & 25.44 & 24.09 & 22.55 & 1.68 & 0.48 \\
\hline $\mathrm{C} 20: 0$ & 0.07 & 0.07 & 0.07 & 0.01 & 0.50 \\
\hline $\mathrm{C} 21: 0$ & 0.05 & 0.11 & 0.06 & 0.03 & 0.19 \\
\hline $\mathrm{C} 22: 0$ & 1.60 & 1.40 & 1.48 & 0.31 & 0.90 \\
\hline C23:0 & 0.22 & 0.24 & 0.27 & 0.02 & 0.10 \\
\hline C24:0 & 0.06 & 0.04 & 0.03 & 0.02 & 0.59 \\
\hline$\Sigma$ SFA & 47.49 & 46.08 & 44.03 & 1.35 & 0.16 \\
\hline \multicolumn{6}{|l|}{ Unsaturated FA (UFA) } \\
\hline C14:1 & 0.20 & 0.18 & 0.20 & 0.03 & 0.84 \\
\hline C15:1 & 0.03 & 0.04 & 0.03 & 0.01 & 0.56 \\
\hline C16:1 & 0.32 & 0.32 & 0.34 & 0.02 & 0.82 \\
\hline C17:1 & 0.07 & 0.08 & 0.08 & 0.01 & 0.78 \\
\hline C18:1 cis-9 & 12.65 & 12.77 & 13.27 & 0.50 & 0.58 \\
\hline C18:1 cis-11 & $0.57^{\mathrm{a}}$ & $0.60^{\mathrm{a}}$ & $0.68^{\mathrm{b}}$ & 0.02 & $<0.01$ \\
\hline $\mathrm{C} 18: 1$ cis-12 & $0.40^{\mathrm{a}}$ & $0.62^{\mathrm{b}}$ & $0.74^{\mathrm{c}}$ & 0.03 & $<0.001$ \\
\hline C18:1 cis-15 & 0.04 & 0.08 & 0.06 & 0.01 & 0.18 \\
\hline C22:1 & 0.82 & 0.85 & 1.25 & 0.31 & 0.55 \\
\hline $\mathrm{C} 24: 1 \mathrm{n}-9$ & 0.46 & 0.48 & 0.47 & 0.04 & 0.74 \\
\hline \multicolumn{6}{|l|}{ trans 18:1 } \\
\hline C18:1 trans $-4-5$ & $0.04^{\mathrm{a}}$ & $0.08^{\mathrm{b}}$ & $0.07^{\mathrm{b}}$ & 0.01 & 0.02 \\
\hline C18:1 trans $-6-8$ & 0.04 & 0.06 & 0.03 & 0.02 & 0.52 \\
\hline C18:1 trans -9 & $0.04^{\mathrm{a}}$ & $0.08^{b}$ & $0.09^{\mathrm{b}}$ & 0.01 & $<0.001$ \\
\hline $\mathrm{C} 18: 1$ trans -11 & 0.36 & 0.40 & 0.40 & 0.03 & 0.35 \\
\hline $\mathrm{C} 18: 1$ trans -12 & $0.19^{\mathrm{a}}$ & $0.26^{\mathrm{b}}$ & $0.27^{\mathrm{b}}$ & 0.02 & $<0.01$ \\
\hline$\Sigma$ trans $18: 1$ & $0.75^{\mathrm{a}}$ & $0.98^{\mathrm{b}}$ & $0.96^{\mathrm{b}}$ & 0.06 & 0.01 \\
\hline$\Sigma$ MUFA & 16.59 & 17.36 & 18.34 & 0.62 & 0.14 \\
\hline C18:2 trans -9, trans -12 & 0.14 & 0.15 & 0.16 & 0.02 & 0.84 \\
\hline C18:2 cis-9,trans-12 & 0.05 & 0.06 & 0.06 & 0.01 & 0.92 \\
\hline C18:2 trans- 9, cis- 12 & 0.09 & 0.12 & 0.12 & 0.02 & 0.36 \\
\hline $\mathrm{C} 18: 2$ cis- 9, cis- 12 & 29.34 & 29.40 & 30.62 & 1.02 & 0.52 \\
\hline C18:2 trans -10, cis -12 & 0.13 & 0.18 & 0.15 & 0.02 & 0.23 \\
\hline C18:2 cis-9,trans-11 & 0.19 & 0.27 & 0.27 & 0.10 & 0.82 \\
\hline C18:3n-6 & 0.30 & 0.30 & 0.32 & 0.04 & 0.75 \\
\hline $\mathrm{C} 18: 3 \mathrm{n}-3$ & $0.93^{\mathrm{a}}$ & $1.03^{\mathrm{ab}}$ & $1.11^{\mathrm{b}}$ & 0.05 & 0.02 \\
\hline $\mathrm{C} 20: 2 \mathrm{n}-6$ & 0.06 & 0.07 & 0.01 & 0.01 & 0.94 \\
\hline $\mathrm{C} 20: 3 n-6$ & 1.13 & 1.22 & 1.16 & 0.28 & 0.97 \\
\hline C20:3n-3 & 0.02 & 0.04 & 0.02 & 0.01 & 0.19 \\
\hline C20:4n-6 & 2.65 & 2.58 & 2.54 & 0.34 & 0.97 \\
\hline $\mathrm{C} 22: 2$ & 0.13 & 0.30 & 0.17 & 0.07 & 0.19 \\
\hline $\mathrm{C} 20: 5 \mathrm{n}-3$ & 0.46 & 0.49 & 0.53 & 0.07 & 0.64 \\
\hline $\mathrm{C} 22: 6 \mathrm{n}-3$ & 0.30 & 0.37 & 0.34 & 0.04 & 0.44 \\
\hline$\Sigma$ PUFA & 35.72 & 36.29 & 37.35 & 1.18 & 0.57 \\
\hline$\Sigma$ UFA & 52.50 & 53.92 & 55.97 & 1.35 & 0.16 \\
\hline SFA:UFA ratio & 0.94 & 0.89 & 0.81 & 0.05 & 0.17 \\
\hline
\end{tabular}

${ }^{\mathrm{a}-\mathrm{c}}$ Treatment means in a row that do not share a common letter are different $(P<0.05)$.

${ }^{1}$ Periods lasted $14 \mathrm{~d}$ with treatments beginning on d 7 postpartum. Samples were taken on d 10 and 14 of each period.

${ }^{2} \mathrm{SAT}=$ EnerGII calcium salts of fatty acids provided by Virtus Nutrition (Corcoran, CA) comprising $3 \%$ of DM; MIX $=1: 1$ mix of SAT and TRANS at $3 \%$ of DM; TRANS $=$ EnerGTR calcium salts of fatty acids provided by Virtus Nutrition comprising $3 \%$ of DM. 
Table 5. Fatty acid composition of plasma NEFA of early lactation Holstein cows $(\mathrm{n}=12)$ fed various fat supplements ${ }^{1}$

\begin{tabular}{|c|c|c|c|c|c|}
\hline \multirow{2}{*}{$\begin{array}{l}\mathrm{FA}, \\
\% \text { of total }\end{array}$} & \multicolumn{3}{|c|}{ Ration $^{2}$} & \multirow[b]{2}{*}{ SEM } & \multirow[b]{2}{*}{$P$-value } \\
\hline & SAT & MIX & TRANS & & \\
\hline \multicolumn{6}{|l|}{$\overline{\mathrm{SFA}}$} \\
\hline $14: 0$ & 1.92 & 1.91 & 1.79 & 0.14 & 0.75 \\
\hline $15: 0$ & $0.47^{\mathrm{a}}$ & $0.55^{\mathrm{b}}$ & $0.48^{\mathrm{a}}$ & 0.02 & 0.04 \\
\hline 16:0 & $24.78^{\mathrm{a}}$ & $25.27^{\mathrm{a}}$ & $23.87^{\mathrm{b}}$ & 0.38 & 0.04 \\
\hline $17: 0$ & 1.22 & 1.23 & 1.20 & 0.05 & 0.91 \\
\hline 18:0 & 32.04 & 31.61 & 31.97 & 0.81 & 0.89 \\
\hline 20:0 & 0.35 & 0.36 & 0.35 & 0.03 & 0.92 \\
\hline $21: 0$ & 0.05 & 0.05 & 0.05 & 0.01 & 0.94 \\
\hline $22: 0$ & 0.60 & 0.57 & 0.52 & 0.08 & 0.80 \\
\hline $23: 0$ & 0.15 & 0.14 & 0.15 & 0.02 & 0.59 \\
\hline 24:0 & 0.24 & 0.19 & 0.22 & 0.03 & 0.30 \\
\hline$\Sigma$ SFA & 61.82 & 61.89 & 60.61 & 1.05 & 0.53 \\
\hline \multicolumn{6}{|c|}{ Unsaturated FA (UFA) } \\
\hline $14: 1$ & 0.21 & 0.17 & 0.18 & 0.03 & 0.51 \\
\hline $16: 1$ & 1.42 & 1.50 & 1.42 & 0.12 & 0.80 \\
\hline $\mathrm{C} 18: 1$ cis-9 & 25.03 & 24.88 & 25.62 & 1.13 & 0.84 \\
\hline C18:1 cis-11 & 0.86 & 0.90 & 1.08 & 0.07 & 0.07 \\
\hline C18:1 cis-12 & $0.43^{\mathrm{a}}$ & $0.48^{\mathrm{b}}$ & $0.58^{\mathrm{c}}$ & 0.02 & $<0.001$ \\
\hline C18:1 cis-13 & $0.15^{\mathrm{a}}$ & $0.15^{\mathrm{a}}$ & $0.20^{\mathrm{b}}$ & 0.01 & $<0.01$ \\
\hline $\mathrm{C} 18: 1$ cis-14 & $0.26^{\mathrm{a}}$ & $0.30^{\mathrm{b}}$ & $0.33^{\mathrm{c}}$ & 0.01 & $<0.001$ \\
\hline C18:1 cis-15 & 0.06 & 0.07 & 0.06 & 0.01 & 0.73 \\
\hline C20:1 & 0.50 & 0.49 & 0.41 & 0.04 & 0.17 \\
\hline \multicolumn{6}{|l|}{ trans $18: 1$} \\
\hline C18:1 trans $-6-8$ & $0.22^{\mathrm{a}}$ & $0.32^{\mathrm{a}}$ & $0.46^{\mathrm{b}}$ & 0.04 & $<0.001$ \\
\hline C18:1 trans -9 & $0.28^{\mathrm{a}}$ & $0.39^{\mathrm{b}}$ & $0.44^{\mathrm{b}}$ & 0.04 & 0.01 \\
\hline C18:1 trans -10 & $0.53^{\mathrm{a}}$ & $0.69^{\mathrm{b}}$ & $0.83^{\mathrm{b}}$ & 0.06 & $<0.001$ \\
\hline $\mathrm{C} 18: 1$ trans -11 & $1.13^{\mathrm{a}}$ & $1.30^{\mathrm{b}}$ & $1.35^{\mathrm{b}}$ & 0.08 & 0.02 \\
\hline $\mathrm{C} 18: 1$ trans- 12 & $0.13^{\mathrm{a}}$ & $0.18^{\mathrm{b}}$ & $0.24^{\mathrm{b}}$ & 0.02 & $<0.01$ \\
\hline$\sum$ trans $18: 1$ & $2.29^{\mathrm{a}}$ & $2.88^{\mathrm{b}}$ & $2.88^{\mathrm{b}}$ & 0.18 & $<0.0001$ \\
\hline$\Sigma$ MUFA & 31.25 & 31.85 & 39.39 & 1.05 & 0.53 \\
\hline C18:2 cis-9,cis-12 & 6.12 & 5.30 & 5.32 & 0.57 & 0.48 \\
\hline C18:3n-6 & 0.07 & 0.07 & 0.07 & 0.01 & 0.99 \\
\hline C18:3n-3 & 0.65 & 0.78 & 0.64 & 0.08 & 0.38 \\
\hline C20:5n-3 & 0.09 & 0.10 & 0.09 & 0.01 & 0.82 \\
\hline$\Sigma$ PUFA & 6.93 & 6.26 & 6.13 & 0.60 & 0.57 \\
\hline$\Sigma \mathrm{UFA}$ & 38.18 & 38.11 & 39.39 & 1.05 & 0.53 \\
\hline UFA:SFA ratio & 0.63 & 0.63 & 0.66 & 0.02 & 0.54 \\
\hline
\end{tabular}

${ }^{\mathrm{a}-\mathrm{c}}$ Treatment means in a row that do not share a common letter are different $(P<0.05)$.

${ }^{1}$ Periods lasted $14 \mathrm{~d}$ with treatments beginning on d 7 postpartum. Samples were taken on $\mathrm{d} 10$ and 14 of each period.

${ }^{2} \mathrm{SAT}=$ EnerGII calcium salts of fatty acids provided by Virtus Nutrition (Corcoran, CA) comprising $3 \%$ of DM; MIX = 1:1 mix of SAT and TRANS at 3\% of DM; TRANS = EnerGTR calcium salts of fatty acids provided by Virtus Nutrition comprising $3 \%$ of DM.

et al. (2000) identified C18:2 trans-10,cis-12 as a potent inhibitor of milk fat synthesis in dairy cows. However, no significant differences in milk fat percentage or concentration of de novo synthesized FA were detected among treatments in the present study (Table $5)$. These findings are consistent with those from a previous study in which calcium salts of TFA failed to alter milk fat percentage (Rodriguez-Sallaberry et al., 2007). Similar to plasma PL, linolenic acid content of milk increased with increasing TFA (Table 6). Dietary TFA increased both total UFA and MUFA; however, changes in total SFA, PUFA, and the ratio UFA:SFA were not detected.

\section{PBMC Gene Expression}

Treatment effects were detected for both $I L 1 \beta$ and ICAM1 mRNA expression (Figures 1 and 2, respectively); however, $T N F-\alpha$ and IL6 gene expression were not affected by treatment (Table 7). Additionally, expression of both IL2 and IL2R $\alpha$, used in this study as indicators of lymphocyte proliferation within the PBMC cell population, were not affected by treatment (Table 7). Expressions of $I L 1 \beta$ mRNA for both the TRANS and MIX treatments were lower $(P<0.001)$ than that of SAT. Expression of ICAM1 mRNA was lower $(P$ $<0.05)$ in the TRANS group than in either the MIX 
WATTS ET AL.

Table 6. Milk FA composition of Holstein cows $(\mathrm{n}=12)$ fed various fat supplements ${ }^{1}$

\begin{tabular}{|c|c|c|c|c|c|}
\hline \multirow{2}{*}{$\begin{array}{l}\text { FA, } \\
\% \text { of total }\end{array}$} & \multicolumn{3}{|c|}{ Ration $^{2}$} & \multirow[b]{2}{*}{ SEM } & \multirow[b]{2}{*}{$P$-value } \\
\hline & SAT & MIX & TRANS & & \\
\hline \multicolumn{6}{|l|}{ SFA } \\
\hline $\mathrm{C} 4: 0$ & 2.29 & 2.38 & 2.34 & 0.08 & 0.73 \\
\hline C6:0 & 1.32 & 1.30 & 1.31 & 0.08 & 0.97 \\
\hline $\mathrm{C} 8: 0$ & 0.70 & 0.68 & 0.68 & 0.06 & 0.91 \\
\hline C10:0 & 1.38 & 1.29 & 1.32 & 0.12 & 0.73 \\
\hline C11:0 & 0.02 & 0.01 & 0.02 & 0.003 & 0.54 \\
\hline $\mathrm{C} 12: 0$ & 1.50 & 1.42 & 1.47 & 0.13 & 0.82 \\
\hline C13:0 & 0.05 & 0.05 & 0.05 & 0.005 & 0.41 \\
\hline C14:0 & 6.12 & 6.04 & 6.04 & 0.38 & 0.97 \\
\hline C15:0 & 0.64 & 0.68 & 0.72 & 0.03 & 0.05 \\
\hline $\mathrm{C} 16: 0$ & $28.83^{\mathrm{a}}$ & $27.28^{\mathrm{a}}$ & $24.46^{\mathrm{b}}$ & 0.68 & $<0.001$ \\
\hline C17:0 & 0.70 & 0.70 & 0.74 & 0.04 & 0.49 \\
\hline C18:0 & 15.11 & 15.82 & 15.82 & 0.68 & 0.73 \\
\hline C20:0 & $0.17^{\mathrm{a}}$ & $0.18^{\mathrm{ab}}$ & $0.19^{\mathrm{b}}$ & 0.01 & 0.03 \\
\hline $\mathrm{C} 21: 0$ & 0.07 & 0.05 & 0.05 & 0.02 & 0.40 \\
\hline $\mathrm{C} 22: 0$ & 0.18 & 0.15 & 0.14 & 0.02 & 0.08 \\
\hline $\mathrm{C} 23: 0$ & 0.04 & 0.03 & 0.03 & 0.01 & 0.58 \\
\hline C24:0 & 0.04 & 0.06 & 0.05 & 0.01 & 0.53 \\
\hline$\Sigma$ SFA & 59.14 & 58.10 & 54.97 & 1.41 & 0.07 \\
\hline \multicolumn{6}{|l|}{ Unsaturated FA (UFA) } \\
\hline C14:1 & 0.31 & 0.34 & 0.33 & 0.03 & 0.56 \\
\hline C16:1 & 1.49 & 1.52 & 1.48 & 0.07 & 0.82 \\
\hline $\mathrm{C} 20: 1$ & $0.54^{\mathrm{a}}$ & $0.65^{\mathrm{b}}$ & $0.73^{\mathrm{c}}$ & 0.03 & $<0.001$ \\
\hline $\mathrm{C} 22: 1$ & 0.15 & 0.14 & 0.14 & 0.01 & 0.55 \\
\hline $\mathrm{C} 24: 1 \mathrm{n}-9$ & 0.08 & 0.05 & 0.07 & 0.02 & 0.49 \\
\hline C18:1 cis-9 & 30.04 & 30.55 & 31.22 & 0.95 & 0.49 \\
\hline $\mathrm{C} 18: 1$ cis-11 & $0.80^{\mathrm{a}}$ & $0.88^{\mathrm{b}}$ & $0.93^{\mathrm{b}}$ & 0.04 & $<0.001$ \\
\hline $\mathrm{C} 18: 1$ cis- 12 & $0.35^{\mathrm{a}}$ & $0.48^{\mathrm{b}}$ & $0.60^{\mathrm{c}}$ & 0.02 & $<0.001$ \\
\hline $\mathrm{C} 18: 1$ cis-13 & $0.08^{\mathrm{a}}$ & $0.13^{\mathrm{b}}$ & $0.18^{\mathrm{c}}$ & 0.01 & $<0.001$ \\
\hline $\mathrm{C} 18: 1$ cis-14 & $0.37^{\mathrm{a}}$ & $0.45^{\mathrm{b}}$ & $0.51^{\mathrm{c}}$ & 0.02 & $<0.001$ \\
\hline C18:1 cis-15 & $0.07^{\mathrm{a}}$ & $0.09^{\mathrm{b}}$ & $0.11^{\mathrm{c}}$ & 0.00 & $<0.001$ \\
\hline \multicolumn{6}{|l|}{ trans $18: 1$} \\
\hline C18:1 trans $-6-8$ & $0.20^{\mathrm{a}}$ & $0.38^{\mathrm{b}}$ & $0.53^{\mathrm{c}}$ & 0.04 & $<0.001$ \\
\hline $\mathrm{C} 18: 1$ trans -9 & $0.10^{\mathrm{a}}$ & $0.17^{\mathrm{a}}$ & $0.32^{\mathrm{b}}$ & 0.04 & $<0.001$ \\
\hline $\mathrm{C} 18: 1$ trans -10 & $0.25^{\mathrm{a}}$ & $0.40^{\mathrm{b}}$ & $0.62^{\mathrm{c}}$ & 0.04 & $<0.001$ \\
\hline C18:1 trans -11 & $0.87^{\mathrm{a}}$ & $1.06^{\mathrm{b}}$ & $1.10^{\mathrm{b}}$ & 0.05 & $<0.01$ \\
\hline $\mathrm{C} 18: 1$ trans -12 & $0.14^{\mathrm{a}}$ & $0.23^{\mathrm{b}}$ & $0.35^{\mathrm{c}}$ & 0.03 & $<0.001$ \\
\hline$\Sigma$ trans $18: 1$ & $1.58^{\mathrm{a}}$ & $2.25^{\mathrm{b}}$ & $2.93^{\mathrm{c}}$ & 0.14 & $<0.001$ \\
\hline$\Sigma$ MUFA & $35.86^{\mathrm{a}}$ & $37.53^{\mathrm{ab}}$ & $39.25^{\mathrm{b}}$ & 1.00 & 0.01 \\
\hline C18:2 cis-9,trans- 12 & $0.13^{\mathrm{a}}$ & $0.16^{\mathrm{b}}$ & $0.18^{\mathrm{c}}$ & 0.01 & $<0.001$ \\
\hline C18:2 trans- 9, cis- 12 & $0.17^{\mathrm{a}}$ & $0.23^{\mathrm{b}}$ & $0.24^{\mathrm{b}}$ & 0.01 & $<0.001$ \\
\hline $\mathrm{C} 18: 2 \mathrm{n}-6$ & 3.05 & 3.09 & 3.11 & 0.10 & 0.75 \\
\hline $\mathrm{C} 18: 2$ trans- 10, cis- 12 & $0.01^{\mathrm{a}}$ & $0.02^{\mathrm{b}}$ & $0.02^{\mathrm{c}}$ & 0.001 & $<0.001$ \\
\hline C18:2 cis-9,trans- 11 & 0.21 & 0.14 & 0.15 & 0.06 & 0.70 \\
\hline C18:3n-6 & 0.03 & 0.03 & 0.03 & 0.003 & 0.16 \\
\hline $\mathrm{C} 18: 3 \mathrm{n}-3$ & $0.36^{\mathrm{a}}$ & $0.39^{\mathrm{b}}$ & $0.40^{\mathrm{b}}$ & 0.01 & $<0.001$ \\
\hline $\mathrm{C} 20: 2 \mathrm{n}-6$ & 0.02 & 0.02 & 0.02 & 0.001 & 0.15 \\
\hline $\mathrm{C} 20: 4 \mathrm{n}-6$ & 0.03 & 0.03 & 0.03 & 0.005 & 0.94 \\
\hline $\mathrm{C} 20: 5 \mathrm{n}-3$ & 0.02 & 0.02 & 0.02 & 0.003 & 0.61 \\
\hline $\mathrm{C} 22: 6 \mathrm{n}-3$ & 0.18 & 0.16 & 0.15 & 0.03 & 0.72 \\
\hline$\Sigma$ PUFA & 4.23 & 4.32 & 4.38 & 0.15 & 0.66 \\
\hline$\Sigma$ UFA & $40.10^{\mathrm{a}}$ & $41.84^{\mathrm{ab}}$ & $43.63^{\mathrm{b}}$ & 1.02 & 0.01 \\
\hline UFA:SFA ratio & 0.69 & 0.72 & 0.93 & 0.09 & 0.16 \\
\hline De novo $^{3}$ & 13.30 & 13.11 & 13.15 & 0.80 & 0.96 \\
\hline
\end{tabular}

${ }^{\mathrm{a}-\mathrm{c}}$ Treatment means in a row that do not share a common letter are different $(P<0.05)$.

${ }^{1}$ Periods lasted $14 \mathrm{~d}$ with treatments beginning on d 7 postpartum. Samples were taken on d 10 and 14 of each period.

${ }^{2} \mathrm{SAT}=$ EnerGII calcium salts of fatty acids provided by Virtus Nutrition (Corcoran, CA) comprising $3 \%$ of DM; MIX $=1: 1$ mix of SAT and TRANS at 3\% of DM; TRANS = EnerGTR calcium salts of fatty acids provided by Virtus Nutrition comprising $3 \%$ of DM.

${ }^{3}$ De novo $=$ sum of C4:0, C6:0, C8:0, C10:0, C12:0, and C14:0. 


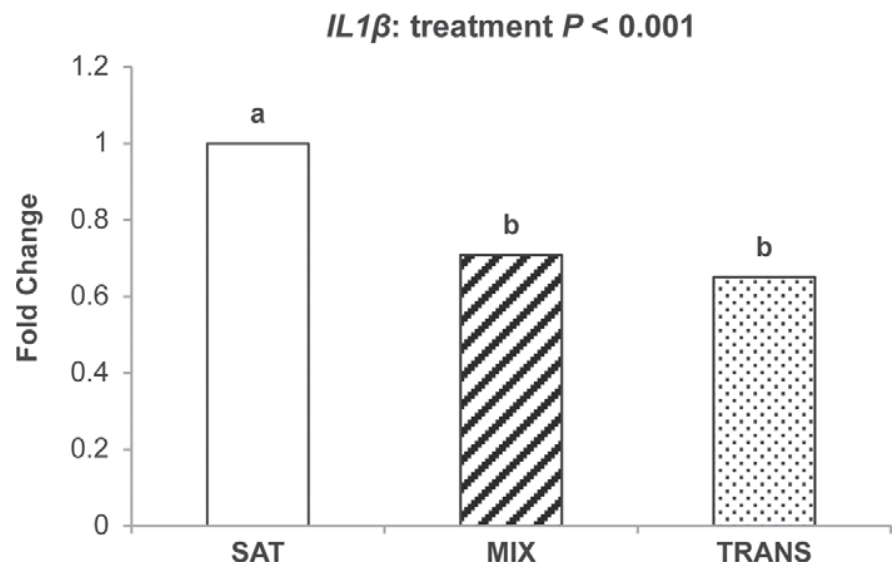

Figure 1. Gene expression (fold change) of IL-1 $\beta$ (IL1 $\beta$ ) in peripheral blood mononucleocytes isolated from cows $(\mathrm{n}=12)$ fed diets supplemented with 3\% SFA:0\% trans FA (SAT), 1.5\% SFA:1.5\% trans FA (MIX), or 0\% SFA:3\% trans FA (TRANS) as percent of DM. Least squares means \pm SEM are illustrated by fold change $\left(2^{-\Delta \Delta \mathrm{Ct}}\right.$ method) relative to SAT treatment. Original $\Delta$ cycle threshold $(\mathrm{Ct})$ values were used for statistical analysis. $\Delta \mathrm{Ct}$ values for $I L 1 \beta$ were $7.92,8.41$, and $8.54( \pm 0.34)$ for SAT, MIX, and TRANS, respectively $(P<0.001)$. Columns without a common letter differ $(P<0.05)$.

or SAT groups. These results are somewhat surprising because in some previous human studies, TFA had a similar proinflammatory effect to SFA (Han et al., 2002; Baer et al., 2004), and TFA treatment has been shown to be a more potent stimulator of adhesion molecules (plasma E-selectin concentration, for example) than SFA (Baer et al., 2004). Also, in at least one bovine tissue (mammary epithelial cells studied in vitro), TFA increased mRNA expression of both IL1 $\beta$ and ICAM1 (Rezamand and McGuire, 2011). However, in the current study, TFA was not delivered directly to cells as was the case in previous cell culture experiments, and thus the more complex process of lipid partitioning may have limited the inflammatory effects of TFA. For instance, we observed that 18:3n-3 (linolenic acid) concentration was increased in plasma PL when cows were fed TFA. The n-3 FA are known to exert antiinflammatory action through altered eicosanoid synthesis and in-

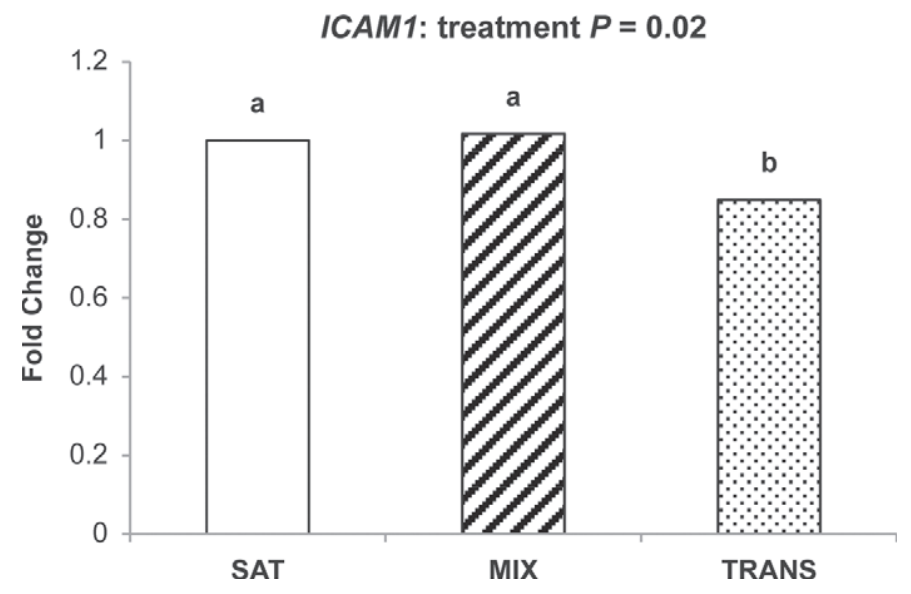

Figure 2. Gene expression (fold change) of intercellular adhesion molecule 1 (ICAM1) in peripheral blood mononucleocytes isolated from cows $(\mathrm{n}=12)$ fed diets supplemented with $3 \%$ SFA:0\% trans FA (SAT), $1.5 \%$ SFA:1.5\% trans FA (MIX), or 0\% SFA:3\% trans FA (TRANS) as percent of DM. Least squares means \pm SEM are illustrated in fold change $\left(2^{-\Delta \Delta \mathrm{Ct}}\right.$ method) relative to SAT treatment. Original $\Delta$ cycle threshold $(\mathrm{Ct})$ values were used for statistical analysis. $\Delta \mathrm{Ct}$ values for ICAM1 were 10.16, 10.13, and $10.39( \pm 0.19)$ for SAT, MIX, and TRANS, respectively $(P=0.02)$. Columns without a common letter differ $(P<0.05)$.

hibition of nuclear factor- $\kappa$ B signaling (Lee et al., 2003; Calder, 2009). Caughey et al. (1996) observed that PBMC concentrations of 18:3n-3 were negatively correlated with production of $I L 1 \beta$ and $T N F \alpha$ in humans. Thus, although n-3 FA of PBMC were not increased by TRANS, circulating concentrations of $18: 3 \mathrm{n}-3$ were greater in cows fed TRANS, which could have elicited an antiinflammatory effect on the PBMC.

The current study demonstrates that gene expression of important inflammatory genes can be modified by dietary FA. Altered gene expression of inflammatory markers could result in disrupted activation and function of innate immune cells such as monocytes, which could have important implications for the resolution of infections during the periparturient period. In the present study, PBMC from SAT-fed cows expressed more ICAM1 mRNA than PBMC from TRANS-fed

Table 7. Gene expression in peripheral blood mononucleocytes isolated from cows fed fat supplements ${ }^{1}$

\begin{tabular}{|c|c|c|c|c|c|}
\hline \multirow[b]{2}{*}{ Gene } & \multicolumn{3}{|c|}{ Ration } & \multirow[b]{2}{*}{ SEM } & \multirow[b]{2}{*}{$P$-value } \\
\hline & SAT & MIX & TRANS & & \\
\hline$T N F \alpha$ & 5.28 & 5.41 & 5.60 & 0.22 & 0.11 \\
\hline IL 6 & 14.58 & 14.64 & 14.92 & 0.27 & 0.20 \\
\hline IL2 & 14.47 & 14.28 & 14.20 & 0.42 & 0.42 \\
\hline$I L 2 R \alpha$ & 9.39 & 9.11 & 9.11 & 0.28 & 0.06 \\
\hline
\end{tabular}

${ }^{1}$ Cows $(\mathrm{n}=12)$ were fed diets supplemented with $3 \%$ SFA:0\% trans FA (SAT), $1.5 \%$ SFA:1.5\% trans FA (MIX), or $0 \%$ SFA: $3 \%$ trans FA (TRANS) as percent of DM. Means \pm SEM are illustrated in $\Delta$ cycle threshold $(\mathrm{Ct})$ values $\left(\mathrm{Ct}_{\text {target gene }}-\mathrm{Ct}_{\text {housekeeping gene }}\right) ; R P S 9$ was used as the housekeeping gene. No significant differences were detected among treatments. 
cows. Immune cells producing increased ICAM1 will more readily bind to endothelial surfaces and transmigrate to tissues such as the mammary gland (Harvey et al., 2008). Increasing the transmigration of leukocytes could be beneficial in the resolution of a mammary infection. On the other hand, the heightened inflammatory response during the periparturient period is a contributor to the severity of economically important diseases such as mastitis and metritis (Sordillo et al., 2009). It is important to note, however, that in the current study, only mRNA expression was measured, and further study is needed to determine how PBMC isolated from cows fed TFA respond to challenge.

Additionally, membrane FA are the substrates for eicosanoid synthesis, and production of less potent eicosanoids is an important aspect of the antiinflammatory properties of n-3 PUFA (Calder, 2009). Although there is currently no evidence in dairy cows that trans monoenes or dienes provide substrate for eicosanoid synthesis, resulting in novel eicosanoids, plasma concentration of prostaglandin $\mathrm{F}_{2 \alpha}$ metabolite was increased when TFA was supplemented in the diet (Rodriguez-Sallaberry et al., 2007), which demonstrates that dietary TFA can alter eicosanoid concentrations. Whether TFA alters synthesis of eicosanoids or somehow affects clearance of prostaglandin $\mathrm{F}_{2 \alpha}$ metabolite is unknown.

\section{Acute Phase Protein}

In the current study, haptoglobin concentration was $0.45 \mathrm{mg} / \mathrm{mL}$ before dietary treatment was initiated on d 7 postpartum. Differences in concentration were not detected among SAT $(0.24 \mathrm{mg} / \mathrm{mL})$, MIX $(0.25 \mathrm{mg} /$ $\mathrm{mL})$, and TRANS $(0.22 \mathrm{mg} / \mathrm{mL})$ cows. These observations suggest that the greater gene expression of inflammatory cytokines detected in the SAT treated cows might have been insufficient to elicit a systemic response in the timeframe tested.

\section{CONCLUSIONS}

The current study demonstrated that dietary FA are efficiently incorporated into plasma lipid fractions and that dietary TFA are incorporated into PBMC lipids. Also, TFA fed at 3\% did not induce inflammatory gene expression in PBMC under our experimental conditions. This indicates that TFA, compared with SFA, may not be proinflammatory to cows, at least when fed at lower amounts $(\leq 3 \%$ of DM). Furthermore, our observation that different dietary treatments did not alter gene expression of IL2 or ILQR $\alpha$ supports previous findings that TFA do not induce lymphocyte proliferation. Finally, this study provides no evidence of negative effects of TFA on DMI, milk production, or milk composition compared with SFA in periparturient dairy cows. Dietary administration of inflammationinducing fats may provide a means of altering the circulating lipid environment in such a way that enables modulation of the immune response of dairy cows, possibly providing a useful tool for management. It should be noted, however, that sampling in the current study did not exactly match the traditional definition of the transition period; the earliest samples were obtained on 17 DIM. Additionally, the use of wash-out period(s) may be considered in future studies, if crossover designs are used.

\section{ACKNOWLEDGMENTS}

The authors thank K. Murphy, S. L. Shields, S. E. Peterson, A. J. Gonzales, and J. K. Kinch (all from University of Idaho, Moscow) for technical assistance with this project as well as J. Peak and his crew at the University of Idaho Dairy Research and Teaching Center for their assistance with animal handling. This project was supported, in part, by Virtus Nutrition (Corcoran, CA) and the Idaho Agricultural Experiment Station (Moscow).

\section{REFERENCES}

Baer, D. J., J. T. Judd, B. A. Clevidence, and R. P. Tracy. 2004. Dietary fatty acids affect plasma markers of inflammation in healthy men fed controlled diets: A randomized crossover study. Am. J. Clin. Nutr. 79:969-973.

Baumgard, L. H., B. A. Corl, D. A. Dwyer, A. Saebø, and D. E. Bauman. 2000. Identification of the conjugated linoleic acid isomer that inhibits milk fat synthesis. Am. J. Physiol. Regul. Integr. Comp. Physiol. 278:R179-R184.

Caldari-Torres, C., A. L. Lock, C. R. Staples, and L. Badinga. 2011. Performance, metabolic, and endocrine responses of periparturient Holstein cows fed 3 sources of fat. J. Dairy Sci. 94:1500-1510.

Calder, P. C. 2008. The relationship between the fatty acid composition of immune cells and their function. Prostaglandins Leukot. Essent. Fatty Acids 79:101-108.

Calder, P. C. 2009. Polyunsaturated fatty acids and inflammatory processes: New twists in an old tale. Biochimie 91:791-795.

Caughey, G. E., E. Mantzioris, R. A. Gibson, L. G. Cleland, and M. J. James. 1996. The effect on human tumor necrosis factor alpha and interleukin 1 beta production of diets enriched in n-3 fatty acids from vegetable oil or fish oil. Am. J. Clin. Nutr. 63:116-122.

Christie, W. W. 1982. A simple procedure for rapid transmethylation of glycerolipids and cholesteryl esters. J. Lipid Res. 23:1072-1075.

Clark, R. M., K. E. Hundrieser, R. G. Jensen, P. B. Brown, A. M. Ferris, and M. Fey. 1982. Changes in the lipids of human milk from 2 to 16 weeks postpartum. J. Pediatr. Gastroenterol. Nutr. $1: 311-315$.

Contreras, G. A., N. J. O'Boyle, T. H. Herdt, and L. M. Sordillo. 2010. Lipomobilization in periparturient dairy cows influences the composition of plasma nonesterified fatty acids and leukocyte phospholipid fatty acids. J. Dairy Sci. 93:2508-2516.

Contreras, G. A., and J. M. Rodríguez. 2011. Mastitis: Comparative etiology and epidemiology. J Mammary Gland Biol. Neoplasia 16:339-356.

Griinari, J. M., B. A. Corl, S. H. Lacy, P. Y. Chouinard, K. V. Nurmela, and D. E. Bauman. 2000. Conjugated linoleic acid is synthe- 
sized endogenously in lactating dairy cows by delta 9-desaturase. J. Nutr. 130:2285-2291.

Han, S. N., L. S. Leka, A. H. Lichtenstein, L. M. Ausman, E. J. Schaefer, and S. N. Meydani. 2002. Effect of hydrogenated and saturated, relative to polyunsaturated, fat on immune and inflammatory responses of adults with moderate hypercholesterolemia. J. Lipid Res. 43:445-452.

Harvey, K. A., T. Arnold, T. Rasool, C. Antalis, S. J. Miller, and R. A. Siddiqui. 2008. Trans-fatty acids induce pro-inflammatory responses and endothelial cell dysfunction. Br. J. Nutr. 99:723-731.

Hristov, A. N. C. Domitrovich, A. Wachter, T. Cassidy, C. Lee, K. J. Shingfield, P. Kairenius, J. Davis, and J. Brown. 2011. Effect of replacing solvent-extracted canola meal with high-oil traditional canola, high-oleic acid canola, or high-erucic acid rapeseed meals on rumen fermentation, digestibility, milk production, and milk fatty acid composition in lactating dairy cows. J. Dairy Sci. 94:4057-4074.

Humblet, M. F., H. Guyot, B. Boudry, F. Mbayahi, C. Hanzen, F. Rollin, and J. M. Godeau. 2006. Relationship between haptoglobin, serum amyloid A, and clinical status in a survey of dairy herds during a 6-month period. Vet. Clin. Pathol. 35:188-193.

Huzzey, J. M., T. F. Duffield, S. J. LeBlanc, D. M. Veira, D. M. Weary, and M. A. von Keyserlingk. 2009. Short communication: Haptoglobin as an early indicator of metritis. J. Dairy Sci. 92:621-625.

Kaluzny, M. A., L. A. Duncan, M. V. Merritt, and D. E. Epps. 1985. Rapid separation of lipid classes in high yield and purity using bonded phase columns. J. Lipid Res. 26:135-140.

Kew, S., T. Banerjee, A. M. Minihane, Y. E. Finnegan, C. M. Williams, and P. C. Calder. 2003. Relation between the fatty acid composition of peripheral blood mononuclear cells and measures of immune cell function in healthy, free-living subjects aged 25-72 y. Am. J. Clin. Nutr. 77:1278-1286.

Lee, J. Y., J. Ye, Z. Gao, H.S. Youn, W.H. Lee, L. Zhao, N. Sizemore, and D.H. Hwang. 2003. Reciprocal modulation of toll-like receptor-4 signaling pathways involving MyD88 and phosphatidylinositol 3-kinase/AKT by saturated and polyunsaturated fatty acids. J. Biol. Chem. 278:37041-37051.

Mozaffarian, D. 2006. Trans fatty acids and cardiovascular disease. N. Engl. J. Med. 354:1601-1613.

Parodi, P. W. 1976. Distribution of isomeric octadecenoic fatty acids in milk fat. J. Dairy Sci. 59:1870-1873.

Petersen, H. H., J. P. Nielsen, and P. M. Heegaard. 2004. Application of acute phase protein measurements in veterinary clinical chemistry. Vet. Res. 35:163-187.

Precht, D., J. Molkentin, F. Destaillats, and R. L. Wolff. 2001. Comparative studies on individual isomeric 18:1 acids in cow, goat, and ewe milk fats by low-temperature high-resolution capillary gasliquid chromatography. Lipids 36:827-832.

Proell, J. M., E. E. Mosley, G. L. Powell, and T. C. Jenkins. 2002. Isomerization of stable isotopically labeled elaidic acid to cis and trans monoenes by ruminal microbes. J. Lipid Res. 43:2072-2076.

Rezamand, P., and M. A. McGuire. 2011. Effects of trans fatty acids on markers of inflammation in bovine mammary epithelial cells. J. Dairy Sci. 94:316-320.

Roach, C., S. E. Feller, J. A. Ward, S. R. Shaikh, M. Zerouga, and W. Stillwell. 2004. Comparison of cis and trans fatty acid containing phosphatidylcholines on membrane properties. Biochemistry 43:6344-6351.

Rodriguez-Sallaberry, C., C. Caldari-Torres, W. Collante, C. R. Staples, and L. Badinga. 2007. Plasma prostaglandin and cytokine concentrations in periparturient Holstein cows fed diets enriched in saturated or trans fatty acids. J. Dairy Sci. 90:5446-5452.

Shields, S. L., P. Rezamand, D. L. Sevier, K. S. Seo, W. Price, and M. A. McGuire. 2011. Effects of increased milking frequency during early postpartum on selected measures of mammary gland health, milk yield, and milk composition. J. Dairy Res. 78:301-307.

Shingfield, K. J., S. Ahvenjärvi, V. Toivonen, A. Vanhatalo, and P. Huhtanen. 2007. Transfer of absorbed cis-9, trans-11 conjugated linoleic acid into milk is biologically more efficient than endogenous synthesis from absorbed vaccenic acid in lactating cows. J. Nutr. 137:1154-1160.

Silvestre, F. T., T. S. M. Carvalho, P. C. Crawford, J. E. P. Santos, C. R. Staples, T. Jenkins, and W. W. Thatcher. 2011. Effects of differential supplementation of fatty acids during the peripartum and breeding periods of Holstein cows: II. Neutrophil fatty acids and function, and acute phase proteins. J. Dairy Sci. 94:2285-2301.

Sordillo, L. M., G. A. Contreras, and S. L. Aitken. 2009. Metabolic factors affecting the inflammatory response of periparturient dairy cows. Anim. Health Res. Rev. 10:53-63.

Steinhart, H., R. Rickert, and K. Winkler. 2003. Trans fatty acids (TFA): Analysis, occurrence, intake and clinical relevance. Eur. J Med. Res. 8:358-362.

Theurer, M. L., E. Block, W. K. Sanchez, and M. A. McGuire. 2009. Calcium salts of polyunsaturated fatty acids deliver more essential fatty acids to the lactating dairy cow. J. Dairy Sci. 92:2051-2056.

Tyburczy, C., A. L. Lock, D. A. Dwyer, F. Destaillats, Z. Mouloungui, L. Candy, and D. E. Bauman. 2008. Uptake and utilization of trans octadecenoic acids in lactating dairy cows. J. Dairy Sci. 91:3850-3861. 